\title{
東北地方の大規模地すべり地形 Large-scale landslide landforms in Tohoku District, Northern Japan
}

清 水 文 健*

Fumitake SHimizu

The large-scale landslide landforms, wish source areas wider than $1 \mathrm{~km}$ were mapped by air-photograph interpretation in the Tohoku district between latitude $38^{\circ} \mathrm{N}$ and latitude $42^{\circ} \mathrm{N}$. On the basis of the mapping, characteristics of the distribution of those large-scale landslide landforms are discussed from geomorpholog. ical and geological points of view.

Six regions are recognized as those of concentration in the central part of the Ou Mountains, the Shirakami Mountains, the Hinotodake-Kamura Mountains and the northern part of the Asahi Mountains. Those regions mostly coincide with the areas of the maximum uplift during the Quaternary time in the Tohoku district. Those are also underlain by the zones of the Lower and Middle Miocene sedimentary rocks and submarine volcanic rocks, commonly called "Green Tuff", and the Quaternary volcanic rocks. The topography in those zones are characterized by cap rock structures.

The large-scale landslide landforms of the Quaternary volcanic areas are dominantly found in the old and/or dormant volcanoes, and are roughly divided into three types from the main contributing factors of landsliding, the volume in source area, morphology and so on.

(1) Type 1 is a catastrophic landslide or collapse of a volcanic cone associated with volcanic activity. Its tophographic and structural feature is composed of the so-called the collapse caldera of the source area and hummocky relief of the deposition area. The latter is a typical topographic feature of volcanic dry avala nche deposits composed of megablocks and interstitial fine material. The volume of the source area is the largest of the three types. Examples can be seen in Iwate volcano, Iwaki volcano, Gassan volcano, Chōkai volcano, Zaō volcano and Shirataka volcano.

(2) Type 2 shows a typical landslide landform associated with a gentle arc-shaped main scarp and a moving mass. Main scarp of this type is found on the slope of a thick lava flow near the top of the volcano.

The activity of the volcanoes, where the landslides of this type occurred, ceased in the late Pleistocene and seems to be almost dormant at present.

The contributing factor to the landsliding may be a large quantity of water supply related to the late Quaternary climatic change.

Water are prepared in the form of the perennial snow patches and are supplied by the rapid melting of the perennial snow patches with the rising air temperature. The formative age of the perennial snow patches ranges from the late Pleistocene to the eariest Holocene (period about 18,000y. B. P. to 8,000y. B. P.).

Because the sea level of this period is lower than that of the present, mountains were vigorously dissected. Then the stability of the mountain slopes rapidly deteriorated and a number of large-scale landslides occured.

Those landslides are found in Hachimantai volcano, Yakeishi volcano, Kurikoma volcano, Funakata volcano, Gassan volcano and $\mathrm{Zaō}$ volcano.

(3) Type 3 is recognized along the dissected vally wall in the pyroclastic deposits and pumice fall deposits. Type of movement is mostly rotational. The volume in source area is smaller than that of the type 2. However, the same contributing factor may be important for the landslides of type 3 as the type 2 .

\section{1. はじめに}

広義の意味の地すべり (landslide) が山地解体の主役 である。線的に作用する河川の侵食に比べ，地すべりは

* 国立防災センター
面的に働くため, とくに規模の大きなるのは, 頻度は少な いが，独立した山体に働いた場合その姿を一変させるこ ともしばしばあり，火山体ではそれが極めて顕著である。 山体から強制的に移動させられた物質は，あまり遠方 まで運ばれることなく，その大部分が山体近くに留まっ 
ていることが多い。活動していることが認識しやすい規 模の地すべり, もしくは, 対策工事等の対象となってい るものの大部分は, このよらな物質の一部が再移動した あのであると考穴てよい。また, 完全に山体から分離せ ずに, 稜線部に, 稜線に平走する逆向きの小崖地形とか 線状凹地などによって, 大規模地すべりの萠芽を暗示す る場合があり, これが自然斜面に和ける最も不安定度の 高い斜面となる。

このように，大規模な地すべり地形に注目することは， 斜面の不安定度を助長し, から新たに作り出すといら点 に扔いて極めて重要であると考光る。本報告では, 北緯 $38^{\circ}$ 線以北の東北地方の大規模地すべり地形 そついて, その分布上の幾つかの特長と問題点に ついて述べる。

\section{2. 地すべりおよび地すべり地形の定義}

「地すべり」の語は広義の意味で使用する。斜 面のある範囲がまとまって斜面下方へ移動する斜 面運動の大部分を含める。したがって, 日本で使 用されている言葉で言えば，地すべり，地すべり 性崩壤, 大規模崩壊, 巨大崩壤, 大規模地すべり, さらに基岩のクリープ等が含まれる。しかし、り リフラクション, 表層上のクリープ, 表層ずベり, 表層崩壊, 土石流, 落石などは含まれない。

「地すべり地形」とは, 上述の意味に特ける地 すべりによって生じた，あるいは生じつつある地 形の総称として使用する。

表題の「大規模地すべり地形」とは, 変動域と 不動域の境界の明確な “単位地すべり地形米” の うち, 主削剶域の最大幅が $1 \mathrm{~km}$ 以上の地すべり 地形のことである。従来は水平面積（寺戸, 1978 など), 移動体の全土量 (崩壊土量) (Machida, 1966など) などによって区別されているが，削㓦 域の最大幅で別けるのが最も簡単かつ個人差なく 地すべり地形の規模を知る指標となり得ると考兄 る(羽田野, 1972)。ちなみに, 主削剝域の最大 幅と移動体の全土量の相関を見ると, 最大幅が 1 $\mathrm{km}$. 以上あれば移動体の土量はずべて Machida （1966）が巨大崩壊として区別した土量 $10^{7} \mathrm{~m}^{3}$ 以 上あると推定できる。

\section{3. 大規模地すべり地形の分布と第四紀 地款変動}

第四紀に持ける急激な地盤の隆起とそれに伴う 活発な下刻作用によって, 山地斜面が不安定化し, 多数の地すべりが発生したであらうことはすでに 指摘されている。

\footnotetext{
1 淔落崖と移動体か゚ワン・セットになった初生地すべり地形
}

図-1は 4 万分の 1 空中写真（国土地理院撮影）の判読 により, 2 万 5 千分の 1 地形図に, 不動域と変動域が明確 に区別される単位地すべり地形の滑落崖と移動体（大き な地すべり地形には内部構造を書入れてある）の輪郭を 記入した図から, 崩壞源の主削剝域の最大幅 $1 \mathrm{~km}$ 以上 の単位地すべり地形を大規模地すべり地形として拾い出 し，それを縮小して大規模地すべり地形の構造の表現を 一切省略して黒色でぬりつぶし, 第四紀地殼変動図No. 6 の接峰面図に重ねたものである。接峰面は, 侵食によっ て生ずる谷を埋め立てた場合に, 各山地が呈するである

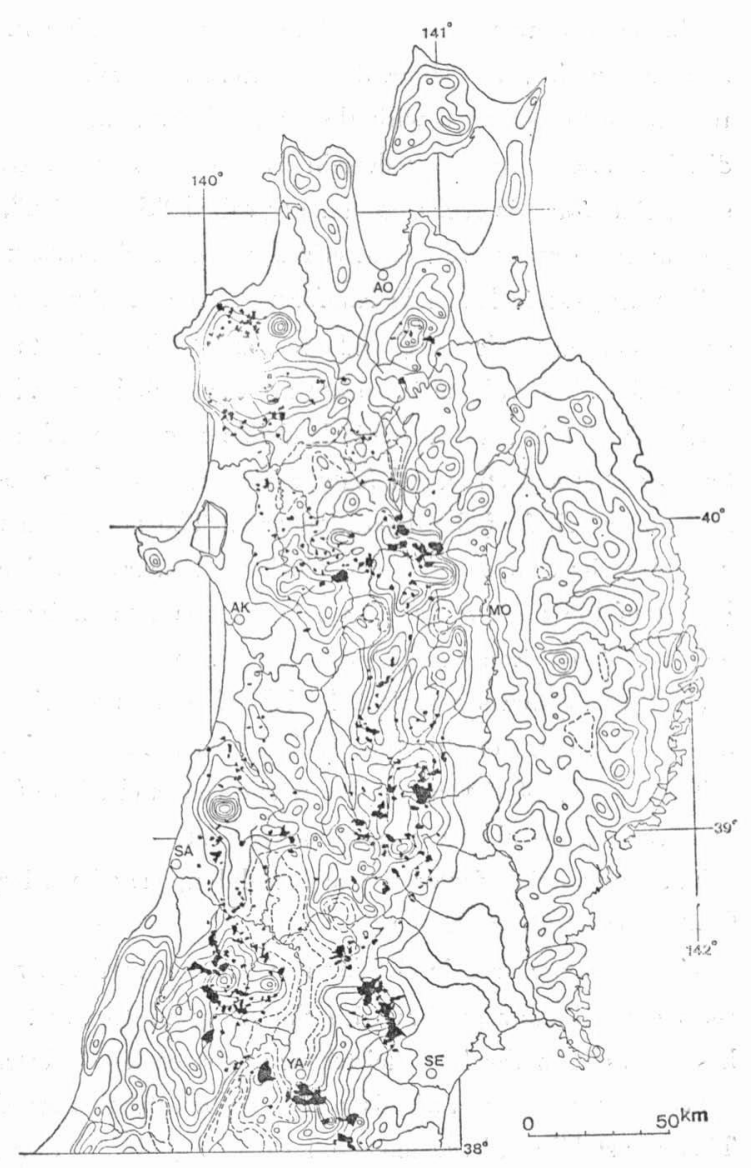

図-1 東北地方の大規模地すべり地形分布図

Fig. 1 Map of the large scale landslides in air-photograph interpretation in the Tohoku District Contor line of Gipfelflur by Okayama, 1969 (interval: 200m, broken line: depression)

大規模地すべり地形 (主削剝域の最大幅が $1 \mathrm{~km}$ 以上のもの, 複倠の 地すべり地形が接している場合は連続してぬられている) 接峰面等高線 (間隔 $200 \mathrm{~m}$ ，破線に凹地）は岡山俊雄編集「接峰面図」( $1: 200$ 万, 第四紀地殻变動図N o. 6, 国立防災科学技術センター, 1969) とよる。 $\mathrm{AO}$ : 青森 $\mathrm{AK}$ : 秋田 $\mathrm{MO}$ : 盛岡 $\mathrm{SA}$ : 酒田 $\mathrm{YA}$ : 山形 $\mathrm{SE}$ : 仙台 $\mathrm{Ha}$ ：八甲田火山 $\mathrm{Td}:$ 十和田火山 $\mathrm{Ik}$ : 岩木火山 $\mathrm{Hm}$ : 八幡平火山 $\mathrm{It}$ : 岩手 火山 Ko：秋田駒ヶ岳火山 $\mathrm{Mo}$ ：森吉火山 $\mathrm{Yk}$ ：焼石火山 $\mathrm{Kg}$ : 栗駒火山 $\mathrm{Ch}$ : 鳥海火山 $\mathrm{Fn}$ :船形火山 $\mathrm{Gs}$ : 月山火山 $\mathrm{Z}_{\mathrm{o}}$ : 蔵王火山 $\mathrm{St}$ : 白鷹火 山 
地すべり斜面の生成とその不安定度に関する諸問題シンポジゥム

らことができる。山地の高さは，一般的には，地盤の垂 直運動の総和と侵食による山頂の低下量とによって決る が，第四紀に激しい地盤運動を蒙った日本では，たとえ 侵食によって細かく谷をらがたれようとも, 山頂の平均 高度差は, 大体地盤運動の総和によって定まる原起伏を 示し, 山地高度の大小は直に地盤運動量の大小を表現し ていると見て差支えない（岡山，1960）から，地盤運動 と大規模地すべり地形の関係を見るのに都合が良い。

図-1の接峰面の等高線に注目すると, 東北地方には二 方向の顕著な等高線の密な地域, すなわら, 隆起量の大 きな地域が認められる。1つは南北方向の高まりで, 山 地名で言觉ば, 奥羽山脈, 出羽山地一朝日山地, も5 1 つは前者に直交する東西方向の高まりを成す白神山地,

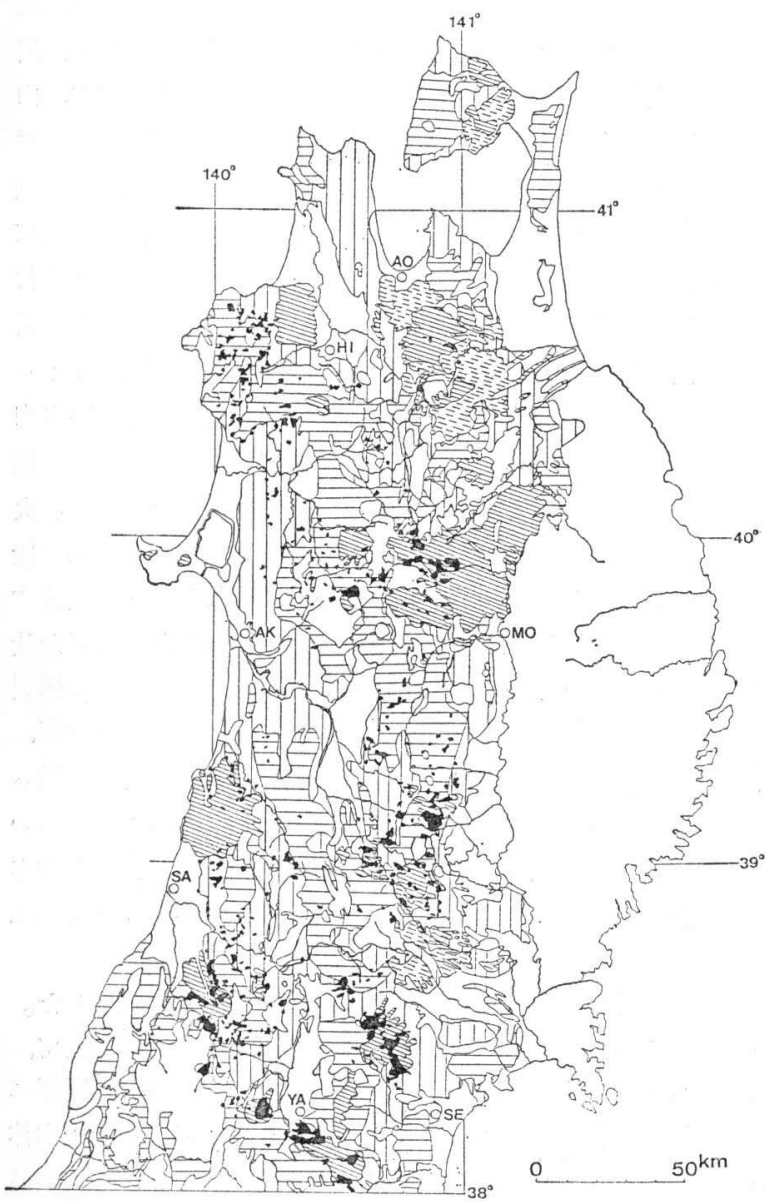

図-2 東北地方の大規模地すべり地形の分布と応用地質区（応用地質 区は大八木ほか，1982による)

Fig. 2. Large scale landslides and Engineering geological map of the Tohoku District

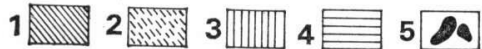

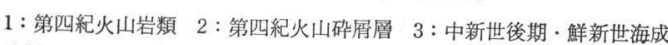
碎首岩 4 : 中新世前·中期堆積岩および同海成火山岩類 5 : 大規模地 すべり地形 $\mathrm{AO}$ : 青森 $\mathrm{HI}$ : 弘前 $\mathrm{AK}$ : 秋田 $\mathrm{MO}$ : 盛岡 $\mathrm{SA}$ : 酒田 $\mathrm{YA}$ : 山形 $\mathrm{SE}:$ 仙台
男鹿半島一太平山地, 丁岳（ひのとだけ）山地である。 これらの高まりの上にはいずれにも火山体がのる。奥羽 山脈の両側には長さの短い活動度 B 級の活断層 (逆断層) が発達する（活断層研究会, 1981)。出羽山地一朝日山 地では活断層よりむしろ活褶曲の発達が著しく，河成段 丘が変形を受けている場合もある。一方，白神山地，男 鹿半島一太平山地では, 日本海の海底に南北方向の活断 層が存在し, 海岸地帯には $5 \sim 6$ 段の海成段丘が発達す る。これらの段丘の高度分布にもとづいた最近数 10 万年 の地盤の変形様式は, 地震性地殼变動と広域的地殼変動 の重なった波長 $20 \sim 30 \mathrm{~km}$ の波状変形で, 現在も継続し て括り（太田·成瀬, 1977; 今泉, 1977), 現在の地形概 形や第四紀垂直変動量の分布様式（第四紀地殼変動図,

1969）と調和している。同じ東西方向の丁岳山地 に打いても，1804年の象潟地震の際, 地震性の隆 起が起り, 震央 (日本海) に近い象潟で最大隆起 量を, そこから南北方向へ向って小さくなる隆起 パターンを示した（平野ほか, 1979). Huzita (19 80）は東北日本を 5 つの活構造带に分けたが，奥 羽山脈, 出羽山地一朝日山地, 太平山地はゾー ン $\mathrm{V}$ に, 白神山地, 男鹿半島はゾーンVV含まれ ている。1983年の日本海中部地震の発生からも明 らかなよらに, 現在では後者の方が活動的である。 大規模地すべり地形は奥羽山脈中部, 白神山地, 太平山地, 出羽山地南部, 丁岳山地, 朝日山地北 部に分布が集中する。これら分布密度の高い地域 は第四紀に拈ける東北地方での最大隆起量が推定 されている地域（前出，1969）で, 非火山地域と 火山地域とから成る。非火山地域には中・小規模 の地すべり地形の発達も極めて良いが, 白神山地 は他に比べて大規模地すべり地形の分布の程度が 著しいように見える。この違いは活構造帯におけ る地盤運動様式执よび活動時期の違いにもとつくく 基盤内部の破壊密度の差によるものか, あるいは, 単に見かけ上そのように見えるだけなのか，今の ところ判断する資料に乏しい。いずれにしても, 地盤運動の活発なところでは, 地震活動も活発で, マグニチュードの小さい地震の長期間にわたる累 積的効果により, 地すべり多発の条件がつくり出 され，稀に起る大きな地震が引金となって，大規 模な地すべりを起すであろうことは十分に考えら れる。その他, 大きな地震によって引起される大 規模な地すべりは，例えば，1984年 9 月の長野県 西部地震による御岳山山腹の崩壊のように, 活火 山や活断層沿いで起る可能性が最も高い。

太平山地では, 隆起量の大きい（等高線の密度 が高い）部分よりむしろ小さい部分に大規模地す ベり地形の分布が著しい。これは図 2 を見れば明 
地すべり Vol.21, No.4 (1985)

らかなように，岩質の違いが顕著に表われたものであろ 5。

大規模な不安定斜面の存在あるいは大規模地すべりの 萠芽を暗示する小崖地形あるいは線状凹地は，東北地方 では37カ所に認められる。とくに奥羽山脈中部の真昼山 地飞発達が良く, 白神山地や太平山地などにはない。し かし, 崖の長さ, 崖高, 崖の明瞭さ, 分布密度のいずれ をとっても，中部山岳地域のそれとは比較…ならないほ ど規模が小さい。東北地方の大小地すべり地形の分布密 度から考えて，扔そらく，すでに主なるのはほとんど滑 ってしまったために，小崖地形の分布密度が低いのであ ろう。それは小崖地形が支稜（支尾根）に主として見ら れることや稜線の両側に発達する地すべり地形の頭部が 互にかみ合って稜線移動を生じている場合が多く認めら れることによっても明らかである。

\section{4. 大規模地すべり地形の分布と地質区}

地すべり地形の分布と地質の関係を知るためには, 単 に通常の地質図に地すべり地形分布図を重ねてみてもあ まり意味はない。なぜなら, 既存の地質図は地層や岩体 の年代や相互関係を表現して拉り, 必ずしも地層名が岩 質を表わしていないし，土木地質的特性はほとんど表現 されていないからである。そこで既存の地質図から応用 地質図への読みかえが必要となる。

図-2は，主に100万分の 1 地質図（地質調查所, 1972） から黒田（1980）によって構成地質の年代と岩質により 区分され，大八木（1981）によって整理された図に大規 模地すべり地形分布図を重ねたものである。

大規模地すべり地形としてピックアップした 531 個の 地すべり地形のうちの $97 \%$, (1)第四紀火山岩類および 火山砕首層, (2)中新世後期 - 鮮新世海成砕屑岩, (3)中新 世前期・中期堆積岩および海成火山岩類の分布地域に集 中する。各地質区に括ける分布の割合は, (1)が25\%, (2) が $21 \%$, (3)が51\%で, (3)の地域での分布の割合が圧倒的 に高くなっている。(1)(2)比べて地質区の分布面積が特 に広いといらわけでもないので, 何か別の条件があると 考えられる。四-1と図-2を並べてながめてみると，(3)の 分布地域は隆起量の大きい地域と一致して括り, 造構応 カによる基盤内部の破壊密度の多朞のほかに, 単純に起 伏量の大小がかなり重要な要因となっているのではない だろらか。(3はいわゆるグリーンタフ地带で, 寺戸（19 80）もすでに述べているように，厚い海成火山岩類がキ ヤップロック構造をなす地域に大規模地すべり地形の分 布密度が高く, (2)の地域では, 厚くて硬い砂岩が同様に キャップロック構造をなす地域に発達する傾向がある。

\section{5. 火山地域の大規模地すべり地形の分布}

本報告の対像地域には，活動中・活動休止中の火山合
わせて24座あり，らち 4 座を除いてすべてが円錐火山で ある (守屋, 1983)。これら全部の火川に山休崩䏅を含 む大規模地すべり地形が認められる。

火山体は火口から放出されたマグマが堆䅡してつくっ た急傾斜で不安定な地形であり, 溶岩と火山灰・火山碎 屑物の硬軟二様の岩質の急傾斜の互層によって構成され， マグマの突き上げによる山体・基盤の变形, 断裂, お上 び, 降水や熱水の進入に伴の変質作用によるぜい弱化, 崩壊誘因としての火山活動と, 地すべりの発生にことか かない条件がそろっている。

火山地域の大規模地すべり地形は, 発生誘因, 崩壊土 量, 形態などから 3 つのタイプに分類される。タイプI はセントヘレンズ火山（U. S. A.）や磐梯火山のような 馬踥形カルデラと流れ山といら組合わせ，もしくは，流 れ山のみによって知られる山頂部の大崩壊タイプで, 岩 木火山, 岩手火山, 鳥海火山, 蔵王火山, 月山火山, 白 鷹火山などに認められ，岩木火山，岩手火山では馬踣形 カルデラがその後の噴火で埋没し, 流れ山のみが大崩壊 のあったことを示している。な拈，藏王火山，鳥海火山 にも同様の状態が認められる。タイプII 近の溶岩流原面に発生し,ゆるい弧状の滑落崖とその前 面に抎がる不規則な凹凸を示す移動体とから成るキャッ プロップ型の地すべり地形で, 活動時期のやや古い火山 体に多く見られ，八幡平火山，焼石火山，栗駒火山，船 形火山，月山火山，藏王火山などに顕著に発達する。火 山体は山体崩壊がなくても, 緻密な岩石から成る山に比 べるとはるかに侵食されやすいが，これらの大規模地す ベり地形のほとんどは滑落崖と移動体がかなり新鮮な状 態で残されている。な抏このタイプには地質図に爆裂 火口とされている例がある。タイプ火砕流堆積面, 降下軽石流堆積面などに掘込まれた開析谷の谷壁に沿っ て見られるスランプ型の地すべり地形で, 堆積物が薄い 場合は剖断面が基盤（ほとんどが第三紀層）内に形成さ れている場合もある。タイプ I, II 比べタイプIIIには 規模の大きいものは少ない。

タイプ I は火山活動に対応して地すべりが発生した。 タイプIIは火山体のもつ数々の不安定要素に加えて, マグマの上昇・下降のくり返しにより形成された断裂に 進入した降水扣よび熱水による变質作用によって火山体 構成層がぜい弱化し, 多量の水の供給あるいは地震が誘 因となって発生したものと推測される。火山活動の後期 ほど火山体の基盤技よび構成層の断裂の密度が高くなり, 火山活動が休止している時間が長いほど割れ目に進入し た降水や熱水による变質作用が進行し，火山体構成㬝の ぜい弱化が進むものと思われる。このように考えると, 活動時期の古い火山により多く大規模地すべり地形の発 達する理由が理解しやすい。

地すべり発生の誘因としては地震と多量の水の供給に 
よる地下水圧の異常増加が考兄られるが，地震の場合は， 活断層が近くに存在する場合は別として，火山活動が休 止状態では地すべりを起させるほどの強さの火山性地震 の発生は期待できない。一方，多量の水の供給は，現在 の気候条件下で大規模地すべりの発生した例はほとんど ないから, 現在より水を多量に供給することが可能な, 現在とは異なった気候条件を考兵る必要がある。水の供 給は夏季の梅雨前線と台風による降水执よび冬季の降雪 が考兄られるが，現在とは異なる気候，すなわち，氷期

（寒冷期）には, 夏季の降水量は減少するから, 冬季の 降雪量と夏季の低温化による越年残雪の増大が重要とな るだろら。そこで次のように考兄られる。寒冷気候下で， 火山体の山頂付近に形成された現在よりはるかに大規模 な多年性雪溪もしくは小水河が，気候の急激な温暖化と ともに融解消失して行く過程で発生した。

タイプ III タタイプ II とほぼ同じ誘因によると考壳る。

\section{6. 大規模地すべり地形の形成年代}

最近，地すべり地形爷する ${ }^{14} \mathrm{C}$ 年代測定資料が増兄 るとともに，地すべり地形の形成年代についての議論が 活発に行われるようになってきたが， ${ }^{14} \mathrm{C}$ 年代測定資料 の産出位置と地すべり地形の内部構造との関係执よび地 すべり地形発達上の位置関係などが不明膫なために，信 頼性に欠ける（星野，1982；古谷なよ゙，1984）。したがっ て, これまでのところ, 形成年代 (主滑落崖の形成時期) を論ずるに必要なデータは少ない。

非火山地域で形成年代が報告されている地すべり地形 のうち，大規模地すべり地形の定義にあてはまるるのは ない。このことは, 現在の気候条件下では大規模な地す べりは発生しにくく，世界的な規模の気候変化でも特に 氷期から間水期あるいは亜氷期から覀間沓期へといった 気候变化の過渡期ないし移行期に，大規模地すべりの発 生条件が生じるものと考えられる。

火山地域の場合, 火山体は各々独立した 1 つのシステ ムであるため, 非火山地域に比べて時代の限定がしやす く, テフロクロノロジーの手法がうまく適用できれば, ${ }^{14} \mathrm{C}$ 年代測定資料やフィッショントラック法による資料 を組込むことによって, 各火山体の大規模地すべり地形 の形成年代が明らかとなるだろう。

タイプI の形成年代は, 火山活動と直接関係があるか ら, 各火山体の詳細な発達史を明らかにすることによっ て判明する。

タイプII, III ついては, 誘因の方からも, 形成年代 決定の枠をはめられるのではないだろらか。

地すべり地形の開析程度から考兄て, 形成年代は拈先 らく最終水期をさかのぼらないだらう。最終水期の敂候 は，北アルプスに括ける氷河の消長から推定すると，(1) $50,000 y$. B. P. 頃に氷河の最大拡大期が認められる。白
馬岳付近では, 皮舌端は標高 $1,100 \mathrm{~m}$ 近くにまで達して いた。間に著しい下刻期（晋間水期）をはさんで，(2) $25,000 \sim 10,000 y$. B. P. 頃に 3 回の氷河の前進があった が，いずれも最大拡大期より大規模で，かつ時代が新し くなるとともに氷河の規模が小さくなる（小疇ほか, 19 74)。

氷河の拡大に最も都合の良い気候条件は, 冬に降雪量 が多く，夏に気温が低い上うな気候であると考兄られる。 北アルプスに拈ける降雪量は日本海の表面水温と蒸発 量によって決まるとされている（小野，1982）。したが って, 氷河の規模が $50,000 y$. B.P. 以降，時代が新しく なるとともに規模が小さくなるということは，降雪量が だんだん減少していったことを意味し，さらに，18,000 y. B. P. の最終水期最寒期には, 海面低下により対島海 流の流入がなく, 表面水温も低下し, 冬季の蒸発量が少 なくなったため，降雪量は著しく減少したものと考えら れる。小笠原 (1975) は当時の日本海の水温が現在より $6^{\circ} \mathrm{C}$ 低く, 蒸発量は現在の $40 \%$ 台であったと推定してい る。しかしながら, 越年雪の発生条件として, ある程度 の降雪さえあれば，前冬の寒暖は問題にならず，むしろ 夏の気候が重要な因子となる（山本，1974）から，現在 の降雨量が 2 分の 1 飞減少しても, 気温が $6^{\circ} \mathrm{C}$ 低下すれ ば，越年雪は形成される（成瀬ほか, 1981)。実際に, 小 規模ながら中部山岳地域に氷河の存在したことは明らか であるから，最寒期に降雪量が極端に減少したとは考え にくい。したがって, 最終水気の最寒期に気温が $7 \sim 8^{\circ} \mathrm{C}$ 低下したことはほぼ確実であるので, 当時, 東北地方の 火山体に現在よりはるかに大規模な各年性雪渓もしくは 小水河が形成されたであるうことは，まずまちがいない だろらら。

Dansgaard ら (1971) はグリーンランド・キャンプ・セ ンチュリーの氷のコアの酸素同位対比の分析から, 過去 約12万年にわたる気候変化を明らかにした。それによる と，10,000y. B.P. 頃を境酒素同位体曲線に著しい変 動が認められる（図-3）。酸素同位体組成 $\delta$ (デルタ） 0 值の変動は海水準変動とほぼ 1 対 1 の対応を示すのが原 則であり，したがって，酸素同位体曲線は地球の放射平 衡温度の変遷をあらわすと考觉られている（小林・阪口， 1977）から，この頃急激な気温上昇のあったことが推測 される。安田（1982）は花粉分析の結果から，日本にお いても $10,000 y$. B. P. 頃を境に急激な温䁔化と積雪量増 加傾向を認めたが，な拈当時の平均気温は現在より 3 $5^{\circ} \mathrm{C}$ 前後低かったと推定している。小泉（1981）の珪藻 群集，大場ほか（1980）の有孔虫の酸素同位対比の分析 結果から, 約 $8,000 y$. B. P. 頃から対鳥海流が日本海へ本 格的に流入し, 海水温は一気に $7 \sim 8^{\circ} \mathrm{C}$ も急上昇したこ とが明らかにされた。これは降雪量の増加傾向を支持す る。さらに, 後立山連峰朝日岳付近で, $8,000 y$. B. P. よ 


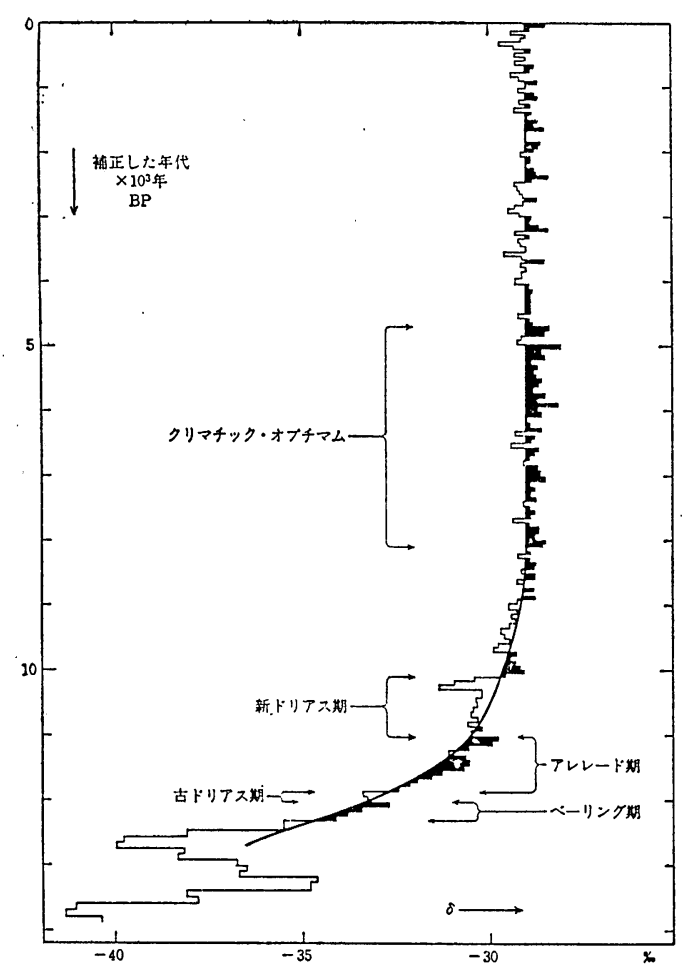

図-3 キャンブ・センチュリーの 1 万 4,000年間の氷のコア の $\delta$ 值 (ダソスガールら, 1971).

Fig. 3 Late glacial and Holocene $\delta$ variations plotted on a corrected time scale.

り新しいプッシュ・モレーンの存在が報告された（小眼 (岡沢，1983).これらのことから考兄て，最終水期最寒 期（18,000y. B. P.）以降 8,000y. B. P. 頃まで，北了ル プスや東北地方の火山体に形成された小水河や多年性雪 渓は，緶小することなく，現在よりはるかに大きな規模 を維持していたと推定される。

完新世の海水準変動曲線は, 6, 000 5, 000y. B. P. に海 面が現在より高かったとする Fairbridge曲線に代表され るタイプ，現在の海水準は完新世の最高位海水準である とするShepard曲線に代表されるタイプ，および，3,600 y. B. P. 以降現在と同じ水準を保っているという Jelgersma 曲線のタイプの 3 つ大大別される（阪口，1983）が, いずれの説に打いても，10,000 8,000y. B. P. 頃の海水 淮は現海面より数 $10 \mathrm{~m}$ 低かったと推定される。

以上の諸点を考光合わせると，10,000y. B. P. から 6, 000y. B. P.のヒプシサーマル期（後氷期の佊暖期）にか けてのある時期，括そらく $8,000 y$. B. P. 前後頃に，父温 の急上昇に伴って，現在よりはるかに大規模な多年性雪 渓もしくは小水河が急速に融解して多量の水が供給され， 游水準の低下と相まって山地内河谷を急激に下刻したた め，地地斜面の不交定化が急速に促進され，大規模な地 す.ベりが発生したものと考える。
非火山地域の大多数の大規模地すべり地形も，扣をら くこの頃形成されたものがかなりあると思われる。

今後 ${ }^{14} \mathrm{C}$ 年代測定資料の産出位置と地すべり地形発達 上の位置関係が明確な信頼にたる资料の急增が待たれ る。

\section{参考文 献}

Dansgaard, W., J. Johnsen, H. B. Clausen and C. C. Langway, Jr. (1971): Climatic record revealed by the Camp Century ice core, in Turekian, K.K., The late Cenozoic glacial ages: New Haven, 37 56.

第四紀地殼変動研究グループ (1969): 第四紀地殼変動図, 国立 防災科学技術センター。

羽田野誠一 (1972)：20万分の 1 「仙台」因幅の大規模地すべり 地形の分布, 日本地理学会予稿集, 3,67, および配布資 料。

平野信一, 中田高, 今泉俊文 (1979) : 象潟地震 (1804年) に伴 与地殻変形 第四紀研究, $18,17 \sim 30$.

古谷尊彦, 宮城豊彦, 日比野紘一郎 (1984):2・3の地すべり地 の年代測定結果について，東北地理，36，201～202.

Huzita, K. (1980) : Role of the Median Tectonic Line in the Quaternary Tectonics of the Japanese Islands. Memoirs of the Geological Society of Japan. No. 18, 129 153.

星野由尚（1982）：ダムサイト適地調查の手法と地すべり地形の 意義，束北地方建設局河川技術资料，111頁。

活断層研究会 (1980)：日本の活断層一分布図と资料一，束大出 版会, 363頁。

黒田和夫 (1980) : Geology and Landslides in Japan. 第 2 回日 米地すべり対策セミナー配布资料。

小畹尚, 杉原重夫, 清水文健, 宇都宮陽二朗, 岩田修二, 岡沢 修一 (1974)：白馬岳の地形学的研究, 駿台史学, 第35号, $1 \sim 86$.

小畹尚, 岡沢修一 (1983): 後立山連峰北部朝日岳の完新世プッ シュ・モレーン, 日本第四紀学会要旨集, $13,110 \sim 111$.

小林国夫 ·阪口豊 (1977)：氷河時代を見直す, 科学, 47,578 591.

小泉格 (1981) : 最終氷期以降の日本海における珠藻捐骸郡集の 変遷。日本第四紀学会要旨集, $11,41 \sim 44$.

Machida, H. (1966) : Rapid Erosional Development of Mountain Slopes and Valleys Caused by Large Landslids in Japan. Geogr. Rep. Tokyo Metr. Univ., 1, 55 78.

守屋以智雄 (1983)：日本の火山地形 (UP Earth Science). 東 大出版会, 135頁。

成瀬廉二, 高橋修平, 藤本強 (1981)：気候変化にともなら北海 道山地の融雪苴変動およびその結果から推定される氷期の 年程雪盖。低温科学, 物理篇, $40,67 \sim 81$.

小笠原和夫 (1975)：日本の氷期の気候, 式正英編 5 日本の氷期 の諸問題」(古今些院), 194 204.

岡山俊雄 (1960)：日本の地形構造一地形誌の出発点として一, 駿台必学, 第 3 号, 28〜38.

小野有五（1982）: 氷河地形による最終水期の降可量の復元と海 水準変動。第四紀研究，21，229～243.

大贴忠道, 堀部純男, 北里洋 (1980)：日本海の 2 本のコアによ る最終水期以降の古環境解析。考古学と自然科学, 13,31 $\sim 49$,

太田隄子, 成瀨洋（1977）：日本の浒成段丘一理太平洋地域の海 面変化, 地殼变動の中での位䘏づけ。科学, 47, 281 292. 
大八木規夫（1981）:地すべり。防災科学技術ゼシナーデギスト， 全国防災協会，27４6.

阪口豊 (1983) : 後水期の海面変動一日本の場合一。地学雑, 92 , $8 \sim 14$.

寺戸恒夫 (1978) : 奥羽山脈中部の大規模 mass movement. 東北 地理, 30, 189 198.

—— (1980) : 古期崩壊地形の分布にみる特性。西村嘉助先
生“退官記念論文集, 94 〜 $98 . ”$

山本武夫 (1974)：日本の気候変動と沖積世の寒冷気候。第四紀 研究, 12, 145 159.

—— (1977)：日本の歴史時代の気候。地理，22，20３5.

安田喜憲 (1982) : 堆積物の各種分析から見た最終永期以降の気 候変動。気象研究ノート，第 147 号, 613 626.

\title{
関東農政局管内の地すべりと崩壊
}

\section{Creep Movement and Steep-Slope Failure in Kantô Region}

\author{
中 山 康* - 西 嶋 輝 之** \\ Yasushi Nakayama · Teruyuki Nishijima
}

\begin{abstract} shown in this paper. slope disasters. They may issue from fossil landslides. river, Nagano prefecture.

\section{1. はしがき}

関東晨政局では地すべり等崩壞災害伦険地調査を実施 したので，その成果を報告する。地すべり扰よび崩壊の 地形を空中写真から判読し，踏査拉よび各種資料からそ の特性を調べ，管内の集計を行った。自然災害の防止と いう観点を重視したので，既に安定している古い地質時 代の地すべり（いわゆる化石地すべり）は省いている。 したがって，人工的な地形改变に対する危険度を示する のではない。
\end{abstract}

The writers plotted a location of active mass movement on a 30 “ $\times 45$ " mesh map. It depends on an observation of a stereoscopic pair of aerophotos and surficial survey. Mass movement lies on the elevated side of thrust fault, an anticlinal axis of active folding and the margin of a tectonic basin. Such statistics are

Itoigawa-Shizuoka tectonic line is a greatest thrust fault which has been identified with a boundary line between Eurasian and North American plates since the Central Japan Sea earthquake 1983.

The division of creep movement and landfall depends on the facies of layer. Clayey soil introduces creep movement and sandy one an accidental fall by heavy....stormy rain or the earthquake. Ancient or fossil mass movement marks are found independent of present crustal movement. Artificial land development may lead

Deposits of dam sites-Miwa, Koshibu, Yasuoka and Hiraoka-are very large along the Tenryû river, which flows through an upheaval district. An occasional mud flow takes its rise at Mt. Hieda along the Ura

\section{2.＼cjkstart地すべりおよび崩壊の分布}

管内の10都県では 1,920 カ所の地すべり・崩填の動き が認められた。位置の表示については, 標準地域メッシ

* 農業土地試験場 造構部

** 関東耤政局 計画部
ニ・システムを採った。滑落崖や移動地塊がメッシュの 一部にかかっていれば，「もり」として扱ら。そのかわ り，メッシュ内に 2 カ所以上の地すべり・崩壊があって も同じく「ありであって，䇫所数を表すことはできな い。メッシュの大きさは，たて $920 \mathrm{~m} \times よ こ 1,130 \mathrm{~m}$ 程度 である。

この分布図からみると，地すべりと崩壊はほぼ次の 3 つの地域に集中している。

(1) 千葉県南部

千葉県下の 230 カ所は，ここに集中している。関東構 造盈地の南縁を形成する房総半島南部から三浦半島を貫 通する嶺岡丹沢隆起带の中軸には, 塩基性火成岩体があ る。蛇紋岩・玄武岩で, 鴨川市太海海岸や横須賀市平作 町明登山なぞには枕状溶岩がみられる。断層を伴ら背斜 構造を持っている第三紀の泥岩は，蛇紋岩と·ともに密集 した地すべり地带を作っている。 